DOI: $10.19195 / 0524-4544.326 .6$

RYSZARD DĄBROWA

Członek Zarządu Głównego ZOSP RP

\author{
PAWEŁ DĄBROWA
}

Państwowa Wyższa Szkoła Zawodowa im. Witelona w Legnicy

\title{
Szkolenie w ochotniczej straży pożarnej w ciągu lat
}

Aby strażak mógł skutecznie realizować zawodową czy społeczną misję, musi nieustannie zwiększać swoją wiedzę, odnawiać ją oraz doskonalić umiejętności. Tylko w taki sposób będzie w stanie odpowiednio wykonywać stojące przed nim zadania, rozwiązywać nowe - wynikające z rozwoju cywilizacyjnego - problemy. Profesjonalne i skuteczne działanie zależy od różnorodnych kompetencji (wiedzy, umiejętności, postaw), które powinny mieć charakter dynamiczny, a więc być ciągle rozwijane i doskonalone. Skuteczne szkolenie rozwija i ugruntowuje wiedzę dającą możliwość podejmowania właściwych decyzji, wpływa też na umiejętność przewidywania i ograniczania zagrożeń w celu zapewnienia bezpieczeństwa podczas prowadzonych działań.

Związek Straży Pożarnych Rzeczypospolitej Polskiej od początku istnienia przywiązywał dużą wagę do szkolenia pożarniczego swoich członków. Zaczęto je prowadzić już przed odzyskaniem niepodległości. W zaborze austriackim duże zasługi na tym polu miał Krajowy Związek Straży Pożarnych Galicji i Lodomerii, który często organizował kursy szkoleniowe dla członków związku. $\mathrm{Na}$ terenie zaboru rosyjskiego również organizowano takie szkolenia jeszcze przed wybuchem pierwszej wojny światowej. Sytuacja w tym zakresie poprawiła się z chwilą utworzenia Związku Floriańskiego w 1916 roku. Od 1917 roku Związek rozpoczął organizację tak zwanych kursów pożarniczych wiosennych i letnich, na których szkolono instruktorów ochotniczej straży pożarnej (dalej: OSP). Poziom szkoleń, a szczególnie czas ich trwania stale się zwiększał - najpierw do czterech, później sześciu, a nawet ośmiu tygodni, a od 1928 roku trwał już cztery 
miesiące. Poszerzał się również zakres programowy — zajęcia teoretyczne i praktyczne na początku obejmowały 160 godzin zajęć, a w 1928 roku aż 760 godzin.

Kursy strażackie prowadził najpierw Zarząd Główny Związku Straży Pożarnych (dalej: ZOSP RP), a z czasem przekazano to zadanie zarządom wojewódzkim, a nawet zarządom powiatowym. Zarząd Główny pozostawił sobie jedynie funkcję nadzorczą, czuwając nad opracowywaniem i wcielaniem w życie instrukcji i podręczników szkoleniowych. Dużo miejsca tym sprawom poświęcała także prasa strażacka. W 1931 roku stworzono instrukcję, która wprowadzała szkolenie w ramach siedmiu stopni, poczynając od strażaka, a na instruktorze pożarniczym kończąc.

Większość kursów była prowadzona przy poszczególnych strażach zawodowych, zwłaszcza przy straży pożarnej w Warszawie, Łodzi i Lublinie, oraz w pomieszczeniach Szkoły Mechaniczno-Technicznej H. Wawelberga i S. Rotwanda. Było to jednak niewystarczające, więc w 1937 roku dzięki staraniom wielu działaczy i władz postanowiono powołać do życia stały ośrodek, w którym kształcono by oficerów i podoficerów zawodowych straży pożarnych i kadrę dowódczą OSP. Na mocy decyzji Ministerstwa Spraw Wewnętrznych ze składek strażaków, dotacji skarbu państwa i PZU na Żoliborzu w Warszawie wybudowano Centralny Ośrodek Wyszkolenia Pożarniczego. Pierwszy kurs oficerski rozpoczął się 1 marca 1939 roku i miał trwać pół roku, ale ze względu na zbliżającą się wojnę został skrócony do pięciu miesięcy. Troska o kształcenie kadry pożarniczej była istotna, ponieważ jej członkowie stanowili siłę motoryczną rozwoju zawodowych i ochotniczych straży pożarnych.

Dynamikę szkolenia kandydatów na oficerów i podoficerów ochotniczych straży pożarnych w ciągu lat przedstawia tabela 1 .

Tabela 1. Przykładowe wyszkolenie kadry ochotniczych straży pożarnych w Polsce w ciągu lat

\begin{tabular}{|c|c|c|c|}
\hline \multirow{2}{*}{ Rok } & \multirow{2}{*}{$\begin{array}{c}\text { Ochotnicze straże } \\
\text { pożarne }\end{array}$} & \multicolumn{2}{|c|}{ Wyszkoleni } \\
\hline & & oficerowie & podoficerowie \\
\hline 1918 & 2095 & 462 & - \\
\hline 1928 & 8176 & 7079 & 5830 \\
\hline 1938 & 12835 & 12895 & 8866 \\
\hline
\end{tabular}

Źródło: J.R. Szaflik, Dzieje ochotniczych straży pożarnych w Polsce, Warszawa 2005, s. 235.

Mimo systematycznego wzrostu liczby wyszkolonych oficerów i podoficerów w stosunku do liczby OSP, braki kadrowe były nadal odczuwalne. Wszystkie działania w zakresie uzupełnienia wyszkolonej kadry podporządkowane były lawinowo narastającym zagrożeniom. 
Po drugiej wojnie światowej powrócił problem szkolenia w powstających strażach pożarnych - zarówno tych zawodowych, jak i ochotniczych czy obowiązkowych.

Oprócz kształcenia formalnego istotnym elementem stało się kształcenie nieformalne, prowadzone przez pracowników komend powiatowych, a potem rejonowych, dowódców oddziałów zawodowych straży pożarnych czy też naczelników ochotniczych oraz obowiązkowych straży pożarnych, polegające na uzupełnianiu oraz aktualizacji wiedzy i umiejętności wymaganych do pełnienia określonych funkcji. Dnia 19 lutego 1974 roku komendant główny straży pożarnych wydał zarządzenie nr 3 w sprawie doskonalenia członków ochotniczych (obowiązkowych) straży pożarnych.

W pierwszym okresie szkolenie pożarnicze podstawowe przeznaczone dla szeregowych członków OSP było prowadzone przez ochotnicze lub obowiązkowe straże pożarne, natomiast ośrodki szkolenia pożarniczego przejęły obowiązek szkolenia funkcyjnych OSP. Szkolenie i doskonalenie członków OSP na poziomie programu I stopnia odbywało się też podczas startu w zawodach pożarniczych.

Członkowie ochotniczych i obowiązkowych straży pożarnych wykonują wiele takich samych zadań jak zawodowi funkcjonariusze pożarnictwa, muszą więc znać obowiązujące przepisy, a także posiadać umiejętności posługiwania się różnorodnym sprzętem gaśniczym oraz niezbędną wiedzę z zakresu taktyki działań. W 1974 roku zarządzeniem Ministra Spraw Wewnętrznych zostały określone zasady organizacji szkolenia pożarniczego, które podzielono na pięć stopni:

— szkolenie szeregowców;

— szkolenie dowódców sekcji;

— szkolenie naczelników OSP typu M;

— szkolenie naczelników OSP typu S;

— szkolenie komendantów gminnych straży pożarnych.

\section{Patrząc w przeszłość, budujemy teraźniejszość}

Reforma systemu ochrony przeciwpożarowej dokonana ustawami o ochronie przeciwpożarowej ${ }^{1}$ i o Państwowej Straży Pożarnej (dalej: PSP) z 1991 roku $^{2}$ spowodowała konieczność ustalenia nowego systemu kształcenia kadr dla jednostek ochrony przeciwpożarowej, również jednostek OSP. Ustawy te przypisały zawodowej formacji ratowniczej główną rolę w zakresie ochrony przeciwpożarowej,

${ }^{1}$ Ustawa z dnia 24 sierpnia 1991 roku o ochronie przeciwpożarowej (Dz.U. z 1991 r. Nr 81, poz. $351 \mathrm{ze}$ zm).

${ }^{2}$ Ustawa z dnia 24 sierpnia 1991 roku o Państwowej Straży Pożarnej (Dz.U. z 1991 r. Nr 88, poz. $400 \mathrm{ze} \mathrm{zm}$.). 
w tym organizację systemów ratowniczych w Polsce, co spowodowało konieczność zmian systemu kształcenia kadr pożarniczych, a powołanie w 1995 roku krajowego systemu ratowniczo-gaśniczego i włączenie doń OSP zrodziło potrzebę przeszkolenia wszystkich szeregowych i funkcyjnych członków tych jednostek.

Należy wspomnieć że lata 1992-1993 to czas funkcjonowania w procesie szkolenia członków OSP rozwiązań przyjętych wcześniej na podstawie programów zatwierdzonych jeszcze przez Komendanta Głównego straży pożarnych i zatwierdzonych przez Prezesa ZOSP RP. Ich celem było przygotowanie członków OSP do prowadzenia działań ratowniczo-gaśniczych głównie we własnych miejscowościach oraz współdziałanie z jednostkami zawodowych straży pożarnych, a później także Państwowej Straży Pożarnej, co pozwoliło na aktywny udział jednostek OSP i PSP w realizacji nowych wyzwań ratowniczych. Rozumiejąc potrzebę dalszego uregulowania zagadnień szkoleniowych, Komendant Główny PSP zarządzeniem nr 1/93 zobowiązał wojewódzkie ośrodki szkolenia PSP, rejonowe ośrodki szkolenia OSP, komendy rejonowe PSP oraz jednostki ratowniczo-gaśnicze PSP do prowadzenia szkoleń członków i funkcyjnych OSP.

Początek 1994 roku przynosi wdrożenie spójnego systemu szkolenia członków OSP na podstawie wprowadzonego 13 stycznia 1994 roku programu szkolenia dla OSP, dającego gwarancję, że absolwenci poszczególnych etapów szkolenia będą dobrze przygotowani do pełnienia funkcji w jednostkach OSP. Program obejmował:

— szkolenie szeregowców OSP;

— szkolenie dowódców OSP;

— szkolenie naczelników OSP;

— szkolenie operatorów sprzętu OSP.

Wdrożenie nowych zasad organizacji szkolenia strażaków ochotników miało również wpływ na wzmocnienie relacji pomiędzy PSP a OSP w zakresie współpracy, nie tylko wynikającej z zapisów aktów prawnych, lecz przede wszystkim z wzajemnych relacji nawiązanych podczas szkoleń i ćwiczeń, co przełożyło się na działania ratownicze, w których wzajemne zaufanie ma ogromny wpływ na jakość wykonywanych czynności.

Powołanie w 1995 roku krajowego systemu ratowniczo-gaśniczego i oparcie go w większości na najlepszych jednostkach OSP zwiększyło zapotrzebowanie na szkolenia członków OSP — zarówno w jednostkach już włączonych, jak i ubiegających się o włączenie do systemu.

Rok 1997 przyniósł kolejne zmiany w związku z wejściem w życie postanowień zawartych w zarządzeniu nr 2/97 Komendanta Głównego PSP z 13 kwietnia 1997 roku związanych z utworzeniem ośrodków szkolenia PSP. Zarządzeniem tym rozwiązano rejonowe ośrodki szkolenia OSP. W 1999 roku nowy zmienił się podział administracyjny kraju. Wraz z powstaniem nowych struktur administracyjnych szkolenie stało się jednym z zadań własnych komendanta miejskiego/powiatowego PSP. Szkoleniami dla OSP zajęły się też szkoły i ośrodki szkolenia PSP. 
Tabela 2. Liczba przeszkolonych członków OSP na dzień 31 grudnia 1999 roku

\begin{tabular}{|l|c|c|c|}
\hline \multicolumn{1}{|c|}{ Rodzaj szkolenia } & $\begin{array}{c}\text { Członkowie } \\
\text { OSP z KSRG }\end{array}$ & $\begin{array}{c}\text { Członkowie } \\
\text { pozostałych OSP }\end{array}$ & Łącznie \\
\hline Szeregowców OSP & 35126 & 105356 & 140482 \\
\hline Dowódców OSP & 10048 & 24022 & 34070 \\
\hline Naczelników OSP & 8741 & 17882 & 26623 \\
\hline Operatorów sprzętu OSP & 9238 & 25433 & 34671 \\
\hline Razem & 63153 & 172693 & 235846 \\
\hline
\end{tabular}

Źródło: Biuletyn informacyjny PSP za rok 1999.

W tym roku też po raz pierwszy rozpoczęto szkolenia członków jednostek operacyjno-technicznych OSP (dalej: JOT OSP) w zakresie ratownictwa medycznego (w 1999 roku przeszkolono 357 członków OSP). Z czasem przygotowanie medyczne członków JOT OSP stało się priorytetowym zadaniem ZOSP RP.

W 2001 roku z inicjatywy komendanta głównego PSP przy współpracy z prezesem Zarządu Głównego ZOSP RP w ramach programu „Fenix 2020” został powołany zespół ekspertów, który prowadził prace nad określeniem sylwetki strażaka ochotnika oraz wprowadzeniem zmian w systemie szkolenia. Prace były kontynuowane przez kolejne zespoły i zaowocowały opracowaniem systemu szkolenia uwzględniającego nowe wyzwania stojące przed strażakami biorącymi bezpośredni udział w działaniach ratowniczych, wprowadzonego w życie 11 maja 2006 roku. Realizatorami systemu szkolenia zostały komendy wojewódzkie i powiatowe/miejskie PSP, a w zakresie kwalifikowanej pierwszej pomocy — ZOSP RP, co zaowocowało stworzeniem tak zwanej ścieżki rozwoju dla strażaków JOT OSP w zakresie wiedzy i umiejętności. Był to przełom w dotychczasowym procesie szkoleniowym. Zastosowane rozwiązania uwzględniały zadania operacyjne realizowane przez strażaków ochotników na miejscu zdarzenia, wychodziły też naprzeciw społecznym oczekiwaniom odnośnie do przygotowania strażaków OSP do wykonywania zadań przeciwpowodziowych i ratownictwa na wodach. System stworzył też możliwość zdobycia umiejętności obsługi nowego sprzętu ratowniczego czy ochronnego, który zaczął trafiać do jednostek OSP: sprzętu ochrony dróg oddechowych, urządzeń hydraulicznych, poduszek ciśnieniowych, kamer termowizyjnych czy urządzeń pomiarowych itp.

Kolejne lata realizacji systemu szkoleniowego przynoszą coraz większą płynność szkoleń, rośnie sprawność organizacyjna jednostek szkolących PSP i ZOSP RP, przybywa również instruktorów przygotowanych do prowadzenia zajęć z członkami JOT OSP.

Bardzo ważnym elementem systemu szkolenia członków OSP biorących bezpośredni udział $\mathrm{w}$ działaniach ratowniczych było przygotowanie i wydanie przez 
Centrum Naukowo-Badawcze Ochrony Przeciwpożarowej w porozumieniu z Zarządem Głównym ZOSP RP materiałów do prowadzenia szkoleń w postaci podręczników i płyt szkoleniowych, a przede wszystkim uruchomienie przez Zarząd Główny ZOSP RP platformy e-learningowej pozwalającej na swobodny wybór terminów rozpoczęcia kursów, indywidualne tempo nauki oraz dostęp do pomocy dydaktycznych.

Osoba, która samodzielnie zrealizowała część teoretyczną programu szkolenia metodą nauki na odległość i zaliczyła tę część, mogła przystąpić do części praktycznej w komendzie powiatowej, miejskiej, wojewódzkiej lub w szkole PSP, co znacznie ułatwiło zdobywanie wiedzy i zwiększyło jej poziom.

Kolejnym kamieniem milowym na drodze budowania skutecznego ratownictwa było podpisanie przez komendanta głównego PSP i dyrektora Lotniczego Pogotowia Ratunkowego (dalej: LPR) 31 lipca 2008 roku porozumienia w sprawie zasad współdziałania LPR z jednostkami ochrony przeciwpożarowej włączonymi do krajowego systemu ratowniczo-gaśniczego. Dzięki temu jednostki OSP stały się ważnym ogniwem współpracy w zakresie współdziałania sił na miejscu działań ratowniczych, ale znowu wymagało to wzbogacenia wiedzy strażaków ochotników o kolejny obszar obejmujący współdziałanie sił ratowniczych ochrony przeciwpożarowej z Samodzielnym Publicznym Zakładem Opieki Zdrowotnej LPR. Przykładowo, w latach 2011-2012 pełne przeszkolenie (część teoretyczną i praktyczną) objęło 13942 członków OSP. Część teoretyczną zaliczyło też 17027 członków OSP, którzy uczestniczyli w części praktycznej w 2013 roku.

W 2011 roku Minister Spraw Wewnętrznych i Administracji wprowadził do użytku służbowego wnioski z ,Analizy potencjału ratowniczego Ochotniczych Straży Pożarnych włączonych do krajowego systemu ratowniczo-gaśniczego". Na tej podstawie określono minimalny standard wyszkolenia członków JOT OSP na poszczególnych poziomach:

— podstawowym - 12 członków;

- dowódców - 2 członków;

— naczelników — 2 członków;

— kierowców - konserwatorów sprzętu - 3 członków;

- ratownictwa technicznego - 4 członków;

— kwalifikowanej pierwszej pomocy — 4 członków;

- kierowania ruchem drogowym - 4 członków;

— zabezpieczenia lądowania LPR — 4 członków.

Celem tej regulacji było osiągnięcie przez członków JOT OSP wyszkolenia i umiejętności praktycznych pozwalających skutecznie prowadzić działania ratownicze. Nie zapomniano też, że o skuteczności kształcenia decyduje wiele czynników, między innymi: motywacja słuchaczy, kompetencje wykładowców i instruktorów, atrakcyjność zajęć, wykorzystywanie nowoczesnych środków dydaktycznych oraz zasad kształcenia. 
Kolejnym krokiem według dokumentu opracowanego w Biurze Szkolenia KG PSP w 2015 roku i uzgodnionego z prezesem ZOSP RP, zatytułowanego „Zasady organizacji szkoleń członków ochotniczych straży pożarnych biorących bezpośredni udział w działaniach ratowniczych", było oparcie zakresu szkolenia strażaków ochotników na wybranych treściach kształcenia podstawowego w zawodzie strażak, co pozwoliło na wykorzystanie wyszkolenia w ramach systemu szkolenia ochotników jako wstępu do szkolenia strażaków PSP — najpierw w zakresie podstawowym w zawodzie strażak, a następnie specjalistycznym, a nawet kształcenia kadry dowódczej jednostek ochrony przeciwpożarowej — zarówno w szkołach aspirantów PSP, jak i Szkole Głównej Służby Pożarniczej.

Zasady uwzględniają również nowe rozwiązania w zakresie ratownictwa specjalistycznego i obejmują:

1. Szkolenia realizowane na poziomie podstawowym, których celem jest przygotowanie do sprawnego i bezpiecznego wykonywania podstawowych czynności ratowniczych, w tym obsługi i konserwacji sprzętu wykorzystywanego do działań ratowniczych.

2. Szkolenia realizowane na poziomie dowódczym, których celem jest przygotowanie strażaków ratowników OSP do kierowania działaniami ratowniczymi na poziomie interwencyjnym, z zachowaniem hierarchii zdobywania umiejętności dowódczych. Jest to istotne z punktu widzenia rozszerzenia działań strażaków ochotników o obszar specjalistycznych czynności ratowniczych. Ma to też wpływ na wzmocnienie relacji między PSP a OSP, co widać podczas działań ratowniczych, w których wzajemne zaufanie oddziałuje na jakość wykonywanych zadań, którymi są czynności ratujące zdrowie, życie i mienie ludzkie.

Do szkoleń poziomu podstawowego zaliczamy szkolenia:

— podstawowe strażaków ratowników OSP;

— kierowców — konserwatorów sprzętu ratowniczego OSP;

- szkolenia realizowane na poziomie specjalistycznym, których celem jest przygotowanie strażaków ratowników OSP do wykonywania działań z użyciem sprzętu specjalistycznego, w który wyposażone są OSP, zgodnie z rodzajem zagrożeń występujących na terenie działania.

Do szkoleń realizowanych na poziomie specjalistycznym należą szkolenia w zakresie:

— ratownictwa technicznego;

- ratownictwa chemicznego i ekologicznego;

— ratownictwa wodnego;

— ratownictwa wysokościowego;

— działań poszukiwawczo-ratowniczych;

— ratownictwa medycznego (realizowane przez ZOSP RP);

— współpracy z LPR.

Do szkoleń realizowanych na poziomie dowódczym zaliczamy: 
— szkolenie kierujących działaniem ratowniczym dla członków OSP (dowódców OSP);

— szkolenie naczelników OSP;

— szkolenie komendantów gminnych ZOSP RP.

\section{Wnioski}

Rola ochotniczych straży pożarnych w systemie bezpieczeństwa wewnętrznego ciągle wzrasta. System ochrony przeciwpożarowej i rozwój cywilizacyjny wymagają bardziej wyspecjalizowanych służb ratowniczych, coraz większej wiedzy ratowników i coraz lepszych umiejętności czy bardziej dynamicznych działań. Wymaga to odpowiedniego przygotowania i nabywania nowych umiejętności przez członków ochotniczych straży pożarnych poprzez lepsze systemy szkoleniowe i systemy doskonalenia umiejętności ratowniczych, na przykład udział w ćwiczeniach doskonalących na poligonach, terenach i obiektach, a także w komorach dymowych czy rozgorzeniowych. Kwestia doskonalenia ma bardzo duże znaczenie, jednak często jest odsuwana na dalszy plan. Pogarsza to jakość działania, zwiększa straty i koszty akcji, zmniejsza bezpieczeństwo ratowników oraz prowadzi do niewykorzystywania możliwości sprzętu i ratowników.

Obszar doskonalenia wymaga szczególnej uwagi i wyraźnego wzmocnienia na szczeblu każdej jednostki. Być może początkowo powinny się tym zająć oddziały wojewódzkie ZOSP RP wspólnie z komendantami wojewódzkimi PSP, następnie to zadanie powinno przejść do jednostek ratowniczo-gaśniczych PSP, a może i niektórych jednostek OSP. W praktyce okazuje się bowiem, że konieczne jest wypracowanie właściwych nawyków myślenia. Wydaje się to oczywiste, ale niektórzy strażacy — przeważnie osoby z małym doświadczeniem nadal nie czują zawodowej lub społecznej misji.

Współczesny strażak ma być wszechstronnie wyszkolonym i przygotowanym profesjonalistą, potrafiącym sprostać każdym, nawet szczególnie wymagającym zadaniom, być sprawny fizycznie i odporny psychicznie. Zachodzi więc stała potrzeba nowelizacji rozwiązań w zakresie procesu szkolenia i doskonalenia strażaków — zarówno PSP, jak i OSP. Dotyczy to nie tylko treści programowych, lecz także sposobu organizacji i realizacji ścieżki szkoleniowej oraz ścisłego powiązania szkolenia członków OSP z kształceniem zawodowym w PSP. Należy uwzględniać także nowe rozwiązania $\mathrm{w}$ zakresie ratownictwa specjalistycznego. Jest to istotne z punktu widzenia rozszerzenia działań strażaków ochotników o obszar specjalistycznych czynności ratowniczych, co przekłada się również na udział w działaniach ratowniczych, gdzie wzajemne zaufanie ma ogromny wpływ na jakość wykonywanych czynności, którymi są tutaj czynności ratujące zdrowie, życie i mienie ludzkie. 


\title{
Bibliografia
}

X lat Państwowej Straży Pożarnej 1992-2002, Komenda Główna Państwowej Straży Pożarnej, Warszawa 2002.

125 lat ,Strażaka”, red. E. Walczak, Warszawa 2007.

Biuletyn informacyjny PSP za rok 1999, Warszawa 2000.

Kociołek-Pęksa A., Decyzja administracyjna i mandat karny w procedurach toczonych przez Państwowa Straż Pożarna w kontekście odpowiedzialności za działania administracji publicznej, [w:] Zbór wybranych opracowań z bloków tematycznych: nauki podstawowe oraz działania ratownicze dla strażaków ubiegających się o zajmowanie stanowisk oficerskich związanych z kierowaniem działaniami ratowniczymi, red. J. Zarzycki, Warszawa 2016.

Kociołek-Pęksa A., Menkes J., Z zagadnień prawnych regulacji systemu bezpieczeństwa narodowego - prawne uwarunkowania logistyki i koordynacji wielopodmiotowych akcji ratowniczych, „Zeszyty Naukowe Szkoły Głównej Służby Pożarniczej w Warszawie” 60, 2016, nr 4.

Krajowy System Ratowniczo-Gaśniczy w latach 1995-2015, red. J. Konieczny, M. Schroeder, Poznań 2015.

Leśniakiewicz W., Rola ochotniczych straży pożarnych w Krajowym Systemie Ratowniczo-Gaśniczym, materiał pokonferencyjny „Z myślą o niepodległej”, Warszawa 2008.

Matusak P., Bolesław Chomicz. W trosce o jedności i siłę ruchu strażackiego, Warszawa 2015.

Matusak P., Bolesław Chomicz i strażacy w odbudowie Odrodzonej Polski, materiał pokonferencyjny „Z myślą o niepodległej”, Warszawa 2008.

Skoczylas J., Prawo ratownicze, wyd. 2, Warszawa 2011.

Szaflik J.R., Dzieje ochotniczych straży pożarnych w Polsce, Warszawa 2005.

Szkolenie pożarnicze w 20-leciu PSP 1992-2012, red. M. Schroeder, S. Mazur, Bydgoszcz 2012.

\section{Wykaz aktów prawnych}

Ustawa z dnia 24 sierpnia 1991 roku o ochronie przeciwpożarowej (Dz.U. z 1991 r. Nr 81, poz. 351 ze zm).

Ustawa z dnia 24 sierpnia 1991 roku o Państwowej Straży Pożarnej (Dz.U. z 1991 r. Nr 88, poz. 400 ze zm.).

\section{The training system of the volunteer fire-fighters}

\author{
Summary
}

To enable fire-fighters to successfully fulfill their responsibilities, they need to constantly improve their skills and broaden their knowledge to help society and to be ready to deal with the new civilization hazards and threats. The legislation of the fire safety law regulations in the 1991 enforce to organize the new education system both for the professional fire management officers and the commanders of the volunteer fire units. Moreover it enables to acquire the new qualifications on the field of the fire safety equipment such as: hydraulic equipment, lifting bags, thermal camera, multi-gas sensor detector. 
All of those qualifications are necessary to broaden the scope of the responsibilities of the volunteer fire-fighters on the area of different specialization, where the common professionalism of firefighters can improve the efficiency of rescue actions.

Keywords: volunteer fire-fighters, training system, qualification, rescue, the state fire service, the national fire and rescue system. 